Original Article

\title{
American visceral leishmaniasis in a state of northeastern Brazil: clinical, epidemiological and laboratory aspects
}

\author{
Leishmaniose visceral americana em estado do nordeste brasileiro: aspectos clínicos, \\ epidemiológicos e laboratoriais
}

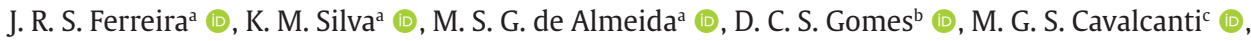

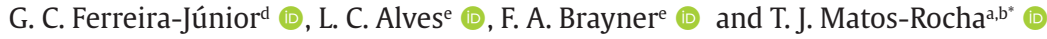 \\ a Universidade Estadual de Ciências da Saúde de Alagoas, Maceió, AL, Brasil \\ ${ }^{\mathrm{b}}$ Centro Universitário Cesmac, Maceió, AL, Brasil \\ c Universidade Federal da Paraíba, João Pessoa, PB, Brasil \\ IInstituto Federal de Educação, Ciência e Tecnologia do Acre - IFAC, Xapuri, AC, Brasil \\ e Departamento de Parasitologia, Instituto Aggeu Magalhães, Recife, PE, Brasil
}

\begin{abstract}
In Brazil, American visceral leishmaniasis (AVL) has become a public health concern due to its high incidence and lethality. This study aimed to analyze the clinical, epidemiological, and laboratory aspects of AVL in a state of Brazil. This descriptive, cross-sectional, retrospective, and quantitative study of notified cases of AVL was carried out in Alagoas between 2008 and 2017 from data obtained from DATASUS/SINAN. Sociodemographic, clinical, and laboratory variables were analyzed. A descriptive analysis was performed using absolute values and valid percentages, using tables and/or graphs. Data processing was performed using Stata $12.0^{\circledR}$. Results with $\mathrm{P}<0.05$ were considered statistically significant. During the study period, 352 cases of AVL were reported, of which $6.82 \%$ died and $38.92 \%$ had met a cure criterion. Male patients were predominant (66.76\%). Of the total infected patients, $16.76 \%$ had attended only the $1^{\text {st }}$ to the $4^{\text {th }}$ grades, with those most affected aged 1 to 4 years $(28.69 \%)$. Laboratory diagnostic criteria were most commonly used to confirm the notified cases (76.42\%), whereas $51.70 \%$ and $8.52 \%$ of the cases had positive parasitological and immunofluorescence diagnoses, respectively. Finally, the study showed a higher prevalence of the disease in children, men and in rural residents. Although with low lethality, the expressive frequency of AVL in the State of Alagoas was still verified, since there was an increase in the number of cases during the years of the study.
\end{abstract}

Keywords: leishmania, epidemiological surveillance, zoonoses.

\begin{abstract}
Resumo
No Brasil, a leishmaniose visceral americana (LVA) tornou-se uma preocupação de saúde pública devido à sua alta incidência e letalidade. Este estudo teve como objetivo analisar os aspectos clínicos, epidemiológicos e laboratoriais da AVL em um estado brasileiro. Este estudo descritivo, transversal, retrospectivo e quantitativo dos casos notificados de AVL foi realizado em Alagoas entre 2008 e 2017 a partir de dados obtidos do DATASUS/SINAN. Foram analisadas variáveis sociodemográficas, clínicas e laboratoriais. Foi realizada uma análise descritiva utilizando-se valores absolutos e percentuais válidos, utilizando tabelas e/ou gráficos. O processamento dos dados foi realizado por meio do Stata $12.0^{\circledR}$. Os resultados com $\mathrm{P}<0,05$ foram considerados estatisticamente significativos. Durante o período de estudo, foram notificados 352 casos de LVA, dos quais 6,82\% morreram e $38,92 \%$ atenderam a um critério de cura. Os pacientes do sexo masculino foram predominantes (66,76\%). Do total de pacientes infectados, $16,76 \%$ tinham sido atendidos apenas do $1^{\circ}$ ao $4^{\circ}$ ano, com os mais afetados entre 1 e 4 anos $(28,69 \%)$. Os critérios de diagnóstico laboratorial foram mais utilizados para confirmar os casos notificados (76,42\%), enquanto 51,70\% e 8,52\% dos casos apresentaram diagnósticos positivos parasitológicos e imunofluorescência, respectivamente. Por fim, o estudo demonstrou maior prevalência da doença em crianças, homens e nos residentes em zona rural. Embora com letalidade baixa, constatou-se ainda a expressiva frequência da LVA no Estado de Alagoas, uma vez que houve aumento do número de casos durante os anos do estudo.
\end{abstract}

Palavras-chave: leishmania, vigilância epidemiológica, zoonoses.

*e-mail: thiago.matos@uncisal.edu.br

Received: May 20, 2020 - Accepted: October 13, 2020

This is an Open Access article distributed under the terms of the Creative Commons Attribution License, which permits unrestricted use, distribution, and reproduction in any medium, provided the original work is properly cited. 


\section{Introduction}

American visceral leishmaniasis (AVL) is a chronic and severe zoonosis, popularly known as Kala-azar in Asia and calazar in Northeast Brazil that is caused by an intracellular protozoan of the genus Leishmania, belonging to the Leishmania donovani complex. AVL can affect the viscera, mainly the spleen, liver, and bone marrow, and can affect humans as well as other mammals. In Brazil, the etiologic agent is Leishmania (Leishmania) infantum chagasi and its most important vector is the female phlebotomine sand fly of the species Lutzomyia longipalpis (Lutz \& Neiva, 1912) (Cortes et al., 2012). In 2017, 20.792 of the 22.145 (94\%) new cases reported to the World Health Organization (WHO) occurred in seven countries: Brazil, Ethiopia, India, Kenya, Somalia, South Sudan, and Sudan. In the WHO Southeast Asia region, the Kala-azar elimination program is progressing satisfactorily, with countries like Bangladesh that reported more than 9.000 cases in 2006 reporting 255 and 192 new cases in 2016 and 2017, respectively (WHO, 2018).

AVL affects all regions of Brazil (21 out of 27 states) and is not controlled, resulting in high lethality rates and significant human and financial impact. Therefore, AVL is considered a public health problem in this country (Brasil, 2016a). From 2010 to 2014, 18.274 cases were confirmed and 1.195 deaths due to AVL were reported in Brazil, corresponding to an average lethality coefficient of $6.5 \%$ (Brasil, 2019). AVL is an endemic disease initially associated with rural areas. However, environmental changes including progressive and disordered urbanization, the deforestation of native forests, population growth, intense migration, and the creation of new neighborhoods, have contributed to the increased disease distribution beyond the endemic areas and the start of an urban cycle (Lobo et al., 2013; Assis et al., 2015).

The prolonged evolution of the disease is classically characterized in the initial phase by an irregular fever of long duration, gastrointestinal disorders such as diarrhea, and abdominal pain, which evolve to a more chronic phase with weight loss, cutaneomucosal pallor, drowsiness, prostration associated with hepatosplenomegaly, anemia, leukopenia, and thrombocytopenia (Aguiar \& Rodrigues, 2017). Diagnosis is made based on clinical and laboratory findings; however, confirmation requires identification of the amastigote forms inside infected tissue. The tests performed include evaluations of blood culture, bone marrow aspirate (the gold standard), spleen, liver, or lymph nodes as well as serological tests such as enzyme-linked immunosorbent assay (ELISA, most commonly used in Brazil) for rK39 (Burza et al., 2018; Queiroz et al., 2004; Pastorino et al., 2002). The Ministry of Health in Brazil recommends pentavalent antimonial $\left(\mathrm{Sb}^{+5}\right)$, known as Glucantime $^{\circledR}$, as the first-choice AVL treatment for nonsevere cases, with amphotericin B reserved for severe cases (Brasil, 2016b).

AVL is a neglected disease and persistent important public health problem in Brazil; however, few studies have assessed its pathology in the state of Alagoas. Epidemiological information on AVL may contribute to the efforts taken to control this endemic disease by helping managers in public health map cases of this parasitosis. Accordingly, this study analyzed the epidemiological, clinical, and laboratory aspects of AVL in the state of Alagoas from 2008 to 2017.

\section{Methods}

This descriptive, cross-sectional, retrospective, and quantitative study of notified cases of AVL was performed in Alagoas from 2008 to 2017. Alagoas has an area of approximately $27,843,295 \mathrm{~km}^{2}$ and an estimated average population of 3,337,357 inhabitants. Data were collected from the website of the IT Department of the Unique Health System (SUS), the public health system in Brazil, known as DATASUS, through the Notifiable Diseases Information System (SINAN).

This study analyzed sociodemographic variables including sex, education, age group, and municipality of residence as well as clinical variables including type of entry, evolution and co-infection/HIV. In addition, laboratory variables were also evaluated as criteria for confirmation, as well as the type of diagnostic method (parasitological or immunological).

Regarding the calculation of lethality, the numbers of deaths were used in the numerator and denominator of the estimated population of the State for each year of the study multiplied by 100,000 , which is the epidemiological indicator of AVL defined by the National Council of Health Secretaries (CONASS) (Brasil, 2016a). The data were saved in Microsoft Office Excel ${ }^{\circledR}$ and checked for consistency. After constructing a database containing the annual values of AVL, a descriptive analysis was performed using absolute values and valid percentages and visualized in tables and/ or graphs. Data processing was performed in Stata $12.0^{\circledR}$.

This study used secondary data available from the official websites of the Ministry of Health of Brazil; as the subjects were de-identified, the study was exempt from research ethics committee approval, in accordance with Resolution 466/2012 of the National Health Council.

\section{Results}

AVL is endemic in the State of Alagoas. Among the study period, 352 cases were reported in Alagoas, from which 48 cases were notified in 2017, the period with the highest number of cases per year, 2016 was the year with the lowest number, registering 24 cases. Regarding the number of deaths, we observed 4 cases of death in the years 2012 and 2014, with deaths recorded in all years of the study (Graph 1).

A total of 352 cases were reported during the study period; males were $(n=235 ; 66.76 \%)$ most affected by AVL, with approximately 2 men for every woman diagnosed. Cases were reported in all age groups, except for those aged 80 or older. The age group with the largest number of confirmed cases was $1-4$ years ( $n=101 ; 28,69 \%$ ), followed by $20-39$ years ( $\mathrm{n}=71 ; 21.88 \%), 10-14$ years $(\mathrm{n}=37 ; 10.51 \%)$, and $5-9$ years $(\mathrm{n}=44 ; 12.50 \%)$ (Table 1$)$. 
Table 1. Demographic variables of confirmed American visceral leishmaniasis (AVL) cases among residents of the state of Alagoas, 2008-2017.

\begin{tabular}{|c|c|c|}
\hline \multirow{2}{*}{ Characteristics } & \multicolumn{2}{|c|}{ Cases } \\
\hline & $\mathbf{N}$ & $\%$ \\
\hline \multicolumn{3}{|l|}{ Education } \\
\hline Illiterate & 34 & 9.66 \\
\hline $1^{\text {st }}$ to $4^{\text {th }}$ grade, incomplete ES & 59 & 16.76 \\
\hline $4^{\text {th }}$ grade, complete ES & 14 & 3.98 \\
\hline $5^{\text {th }}$ to $8^{\text {th }}$ grade, incomplete ES & 34 & 9.66 \\
\hline Complete ES & 10 & 2.84 \\
\hline Incomplete high school & 10 & 2.84 \\
\hline Complete high school & 7 & 1.99 \\
\hline Incomplete college education & 0 & 0.00 \\
\hline Complete college education & 1 & 0.28 \\
\hline Not applicable & 144 & 40.91 \\
\hline Ignored/Blank & 39 & 11.08 \\
\hline \multicolumn{3}{|l|}{ Age group (years) } \\
\hline$<1$ & 24 & 6.82 \\
\hline $1-4$ & 101 & 28.69 \\
\hline $5-9$ & 44 & 12.50 \\
\hline $10-14$ & 37 & 10.51 \\
\hline $15-19$ & 28 & 7.95 \\
\hline 20-39 & 77 & 21.88 \\
\hline $40-59$ & 31 & 8.81 \\
\hline $60-64$ & 7 & 1.99 \\
\hline $65-69$ & 1 & 0.28 \\
\hline $70-79$ & 2 & 0.57 \\
\hline $80+$ & 0 & 0.00 \\
\hline \multicolumn{3}{|l|}{ Sex } \\
\hline Male & 235 & 66.76 \\
\hline Female & 117 & 33.24 \\
\hline \multicolumn{3}{|l|}{ Area of residence } \\
\hline Urban & 93 & 26.42 \\
\hline Rural & 227 & 64.49 \\
\hline Peri-urban & 28 & 7.95 \\
\hline Ignored/Blank & 4 & 1.14 \\
\hline
\end{tabular}

ES: Elementary School

Among these cases, there was a low level of education, with approximately $9.66 \%$ illiterate and $16.76 \%$ with incomplete elementary education (Table 1 ). The level of education was not recorded in approximately $40.91 \%$ of cases; therefore, this factor was excluded from the analysis. Regarding the area of residence, 227 (64.69\%) of the individuals affected by AVL in Alagoas were residents of rural areas, followed by 93 (26.42\%) and 28 (7.95\%) in the urban and peri-urban areas, respectively (Table 1 ).
Table 2. Clinical variables of confirmed American visceral leishmaniasis (AVL) cases among residents of the state of Alagoas, 2008-2017.

\begin{tabular}{lcc}
\hline \multirow{2}{*}{ Characteristics } & \multicolumn{2}{c}{ Cases } \\
\cline { 2 - 3 } Type of entry & n & \\
New case & 337 & 95.74 \\
Relapse & 4 & 1.14 \\
Transfer & 3 & 0.85 \\
Ignored/Blank & 8 & 2.27 \\
Evolution & & \\
Cure & 137 & 38.92 \\
Abandonment & 3 & 0.85 \\
Death from AVL & 24 & 6.82 \\
Death from another cause & 13 & 3.69 \\
Transfer & 25 & 7.10 \\
Ignored/Blank & 150 & 42.61 \\
HIV Co-infection & & \\
Yes & 23 & 6.53 \\
No & 198 & 56.25 \\
Ignored/Blank & 131 & 37.22 \\
\hline
\end{tabular}

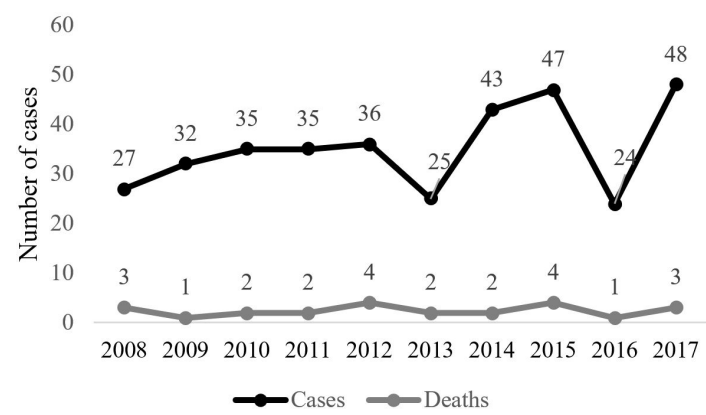

Graph 1. Number of deaths and confirmed cases of AVL in Alagoas between 2008 and 2017.

During the study period, among 352 total cases, 337 (95.74\%) were new cases of AVL, 3 were relapses, 4 were transfers, and 8 cases were unknown. Analysis of the disease course showed that $137(38,92 \%)$ cases were cured, 3 abandoned treatment, 25 were transferred due to changes in city, 24 (6.82\%) died due to AVL, and 150 cases (42.61\%) unknown. Investigation of possible associated infections showed that 23 (6.53\%) individuals affected by AVL were HIV-positive.

Regarding confirmation criteria, the laboratory confirmed $76.42 \%$ of cases. Most of the samples (76.42\%) used laboratory criteria for confirmation, following by clinical-epidemiological criteria (23.58\%). Positive parasitological and immunofluorescence diagnoses 
Table 3. Laboratory variables of confirmed American visceral leishmaniasis (AVL) cases among residents of the state of Alagoas, 2008-2017.

\begin{tabular}{lcc}
\hline \multirow{2}{*}{ Characteristics } & \multicolumn{2}{c}{ Cases } \\
\cline { 2 - 3 } & n & $\%$ \\
\hline Parasitological diagnosis & 182 & 51.70 \\
Positive & 57 & 16.19 \\
Negative & 107 & 30.40 \\
Not performed & 6 & 1.70 \\
Ignored/Blank & & \\
Immunofluorescence (IF) diagnosis & 30 & 8.52 \\
Positive & 21 & 5.97 \\
Negative & 295 & 83.81 \\
Unperformed & 6 & 1.70 \\
Ignored/Blank & & \\
Confirmatory criteria & 269 & 76.42 \\
Laboratory & 83 & 23.58 \\
Clinical-epidemiological & & \\
\hline
\end{tabular}

were observed in $51.70 \%$ and $8.52 \%$ of cases, respectively (Table 3). The mortality rates peaked in 2008 and 2012, at $11.11 \%$ while the lowest rate occurred in 2009 , at $3.13 \%$.

\section{Discussion}

In Brazil, AVL is a parasitic infection that traditionally affects males due to their increased exposure to the invertebrate host related to their occupational activities outdoors (Barbosa, 2016; Gusmão et al., 2014). Even with a wide occurrence in the State of Alagoas, a gradual increase in the frequency of AVL has been observed in recent years. Other Brazilian studies that sought to detect a distribution pattern of AVL recorded similar results, such as the research conducted by Diniz et al. (2018) in the cities of Petrolina-PE and Juazeiro-BA and Barbosa (2016) in the city of Natal-RN, Camargo-Neves et al. (2001) in the city of Araçatuba-SP, the study by Lopes et al. (2010) in Belo Horizonte-MG, and that of Dantas-Torres and Brandão Filho (2006) in the state of Pernambuco. The studies mentioned showed that there was an increase in the number of cases of AVL.

In the present study, more than half of the cases of AVL (58.53\%), occurred in children under 15 years of age, thus characterizing AVL as an infection that occurs in childhood, possibly due to the immaturity of the immune system as well as immunosuppression induced by malnutrition and starvation in some cases (Lima et al., 2018; Brasil, 2017). Furthermore, in our study, the 1-4-year age group was most affected, consistent with previous reports (Sousa et al., 2020; Brandão et al., 2017; Cavalcante and Vale, 2014). Throughout the country, it is observed that, traditionally, there is a higher prevalence of the disease in younger individuals, in which the main affected group is children under the age of ten, which represents a significant up to $58 \%$ of cases (Brasil, 2017).

Our results showed a low level of education, with most cases being illiterate patients with incomplete elementary education. However, information on education was not available for $51.99 \%$ of cases. These findings were similar to those described by Cavalcante and Vale (2014) and Sousa et al. (2020) who also reported high percentages data classified as "not applicable" (Sousa et al., 2020; Cavalcante \& Vale, 2014). This finding may be associated with the fact that patients under 5 years of age, who do not yet attend elementary school and that this age group corresponds to $35.51 \%$ of the cases affected by AVL (Sousa et al., 2020; Alves \& Fonseca, 2018). This education profile has been reported previously and helps to explain the importance of education related to health and prevention of infectious and parasitic diseases, especially in endemic areas, since our results also showed that individuals with low education comprised the majority of patients (Alves \& Fonseca, 2018; Sousa et al., 2018; Barbosa et al., 2013).

In many Brazilian states, the territorial expansion of AVL may be associated with human immigration with parasitized dogs; as indicated by the increased numbers of cases in medium and large cities in Brazil (Scandar et al., 2011). A study in Sergipe reporting the highest AVL occurrence in urban areas supports this possibility (Santos et al., 2018). Mortality due to AVL is worrying in several regions of the world. Regarding evolution, we observed a high cure rate and low number of deaths when patients received adequate treatment for AVL. Results like ours have been described in other regions (Sousa et al., 2020; Santos et al., 2018; Santos et al., 2017). Higher death rates than those in our study were reported in the city of Bauru (SP), in which $8.1 \%$ of individuals died (Ortiz and Anversa, 2015). In another study in Campo Grande (MS), the reported lethality rate was 18.4\% (Alvarenga et al., 2010). However, in Cavalcante and Vale (2014), high lethality rates were observed mainly in children under 1 year of age and elderly people over 60 years (Cavalcante and Vale, 2014). Delayed AVL treatment can worsen patient prognosis; thus, the sooner the confirmatory diagnosis is made, and treatment started, the greater the chances of recovery (Brasil, 2016a). Therefore, endemic regions must have health services with trained professionals, laboratory tests, and medicines to meet demand (Santos et al., 2018).

Regarding entry type, our results were similar to those reported previously (Sousa et al., 2020; Sousa et al., 2018). In Brazil, the diagnosis of AVL can be made based on clinical symptoms presented by the patient due to non-specific laboratory findings from molecular and serological tests. However, parasitological diagnosis is typically made by visualizing the amastigote form of the parasites in bone marrow aspirate (gold standard) (Brasil, 2016a). Although AVL confirmation occurs mainly based on laboratory criteria (Table 3), our results were lower than those reported in São Luís (MA), in which $88.31 \%$ of cases used laboratory criteria for confirmation and $11.69 \%$ had clinical-epidemiological confirmation (Sousa et al., 2020). The diagnosis of visceral leishmaniasis is based on the clinical examination of symptoms and patient-provided 
history, however laboratory diagnosis should be carried out for accurate confirmation of the disease, this can be done by ELISA serological assays and/or indirect immunofluorescence and parasitological examination, through the material collected by puncture in the liver, spleen or bone marrow (Oliveira et al., 2017).

The coexistence of HIV and leishmania, recorded since the 1980 s, causes increased severity of both diseases; thus, this co-infection is considered an emerging (Henn et al., 2018; Brasil, 2011). Some published studies have reported this coinfection in Brazil. In our study observed a low percentage of co-infection (Table 2). In São Luís (MA), 244 patients (14.34\%) were co-infected with human immunodeficiency virus (HIV), however, this information was largely ignored (Sousa et al., 2020). The concern regarding HIV-leishmania co-infection is based mainly on the increased mortality rate. Cavalcante reported increased lethality in adult individuals aged 20-59 years in whom lethality is generally low in the absence of HIV (Cavalcante and Vale, 2014).

This study allowed the epidemiological evaluation of the incidence of AVL in Alagoas, from 2008 to 2017. Regarding epidemiological characteristics, we highlight the predominance of cases in specific groups, such as male gender, high occurrence in the age group from 1 to 4 years, and lower levels of schooling, especially from the $1^{\text {st }}$ to $4^{\text {th }}$ grades. With regard to the area of residence, most cases individuals reside in rural areas. It was also observed that parasitological diagnostic criteria was the most used to confirm the reported cases. Regarding the method used for diagnosis, the present study presented a high percentage of confirmation through the clinical and laboratory criteria. During the analysis of the study period, the low percentage of co-infection with HIV was seen. Among the prophylactic measures, the Zoonosis Surveillance Unit should constantly inspect risk areas for AVL to identify and control infected dogs. In addition, health teams should inspect endemic areas and guide populations at risk for prophylactic measures.

\section{References}

AGUIAR, P.F. and RODRIGUES, R.K., 2017. Leishmaniose visceral no Brasil: artigo de revisão. Revista Unimontes Científica, vol. 19, no. 1, pp. 191-204.

ALVARENGA, D.G., ESCALDA, P.M.F., COSTA, A.S.V. and MONREAL, M.T.F.D., 2010. Leishmaniose visceral: estudo retrospectivo de fatores associados à letalidade. Revista da Sociedade Brasileira de Medicina Tropical, vol. 43, no. 2, pp. 194-197. http://dx.doi. org/10.1590/S0037-86822010000200017. PMid:20464152.

ALVES, W.A. and FONSECA, D.S., 2018. Leishmaniose visceral humana: estudo do perfil clínico-epidemiológico na região leste de Minas Gerais, entre 2008-2015. Journal of Health E' Biological Sciences, vol. 6, no. 2, pp. 133-139. http:// dx.doi.org/10.12662/2317-3076jhbs.v6i2.1764.p133-139.2018.

ASSIS, T.S., GUIMARÃES, P.N., OLIVEIRA, E., PERUHYPE-MAGALHÃES, V., GOMES, L.I. and RABELLO, A., 2015. Study of implementation and direct cost estimates for diagnostic tests for human visceral leishmaniasis in an urban area in Brazil. Cadernos de Saude Publica, vol. 31, no. 10, pp. 2127-2136. http://dx.doi. org/10.1590/0102-311X00158614. PMid:26735380.
BARBOSA, I.R., 2016. Leishmaniose visceral humana no município de Natal-RN: análise clínico-epidemiológica e espacial. Revista Ciência Plural, vol. 2, no. 1, pp. 89-101.

BARBOSA, I. R., SILVA NETO, R. D., SOUZA, P. P., SILVA, R. A., LIMA, S. R., CRUZ, I. D. S. and COSTA, I. C. C., 2013. Aspectos da Coinfecção Leishmaniose visceral e HIV no Nordeste do Brasil. Revista Baiana de Saúde Pública, vol. 37, no. 3, pp. 672-687. https://doi. org/10.22278/2318-2660.2013.v37.n3.a439.

BURZA, S., CROFT, S.L. and BOELAERT, M., 2018. Leishmaniasis. Lancet, vol. 392, no. 10151, pp. 951-970. http://dx.doi.org/10.1016/ S0140-6736(18)31204-2. PMid:30126638.

BRANDÃO, E., ROMERO, S., DA SILVA, M.A.L. and SANTOS, F.L.N., 2017. Neglected tropical diseases in Brazilian children and adolescents: data analysis from 2009 to 2013. Infectious Diseases of Poverty, vol. 6, no. 1, pp. 154. http://dx.doi.org/10.1186/ s40249-017-0369-0. PMid:29096720.

BRASIL. Ministério da Saúde. Secretaria de Vigilância em Saúde. Departamento de Vigilância Epidemiológica. Manual de recomendações para diagnóstico, tratamento e acompanhamento de pacientes com a coinfecção Leishmania-HIV. Brasília: Ministério da Saúde, 2011. 33 p.

BRASIL. Ministério da Saúde. Secretaria de Vigilância em Saúde. Coordenação-Geral de Desenvolvimento da Epidemiologia em Serviços. Guia de Vigilância em Saúde: [recurso eletrônico]. 1. ed. Brasília: Ministério da Saúde, 2016a.543 p.

BRASIL. Ministério da Saúde. Secretaria de Vigilância em Saúde. Coordenação-Geral de Desenvolvimento da Epidemiologia em Serviços. Guia de Vigilância em Saúde. 1. ed. Brasília: Ministério da Saúde, 2016b.

BRASIL. Ministério da Saúde. Secretaria de Vigilância em Saúde. Coordenação-Geral de Desenvolvimento da Epidemiologia em Serviços. Guia de Vigilância em Saúde: volume 3. 1. ed. Brasília: Ministério da Saúde, 2017. 534 p.

BRASIL. Ministério da Saúde. Secretaria de Vigilância em Saúde. Coordenação-Geral de Desenvolvimento da Epidemiologia em Serviços. Guia de Vigilância em Saúde: volume único [recurso eletrônico]. 3. ed. Brasília: Ministério da Saúde, 2019.523 p.

CAVALCANTE, I.J.M. and VALE, M., 2014. Aspectos epidemiológicos da leishmaniose visceral (calazar) no Ceará no período de 2007 a 2011. Revista Brasileira de Epidemiologia, vol. 17, no. 4, pp. 911-924. http:// dx.doi.org/10.1590/1809-4503201400040010. PMid:25388491.

CAMARGO-NEVES, V. L., KATZ, G., RODAS, L. A., POLETTO, D. W., SPÍNOLA, R. M. and CRUZ, O. G., 2001. Use of spatial analysis tools in the epidemiological surveillance of American visceral leishmaniasis, Araçatuba, São Paulo, Brazil, 1998-1999. Caderno de Saúde Pública, vol. 17, no. 5, pp. 1263-1267. http://dx.doi. org/10.1590/s0102-311x2001000500026.

CORTES, S., VAZ, Y., NEVES, R., MAIA, C., CARDOSO, L. and CAMPINO, L., 2012. Risk factors for canine leishmaniasis in an endemic Mediterranean region. Veterinary Parasitology, vol. 189, no. 2-4, pp. 189-196. http://dx.doi.org/10.1016/j.vetpar.2012.04.028. PMid:22575278.

DANTAS-TORRES, F. and BRANDÃO-FILHO, S.P., 2006. Expansão geográfica da leishmaniose visceral no Estado de Pernambuco. Revista da Sociedade Brasileira de Medicina Tropical, vol. 39, no. 4, pp. 352-356. http://dx.doi.org/10.1590/S003786822006000400007. PMid:17119750.

DINIZ, L.F.B., SOUZA, C.D.F. and CARMO, R.F., 2018. Epidemiology of human visceral leishmaniasis in the urban centers of the lower-middle São Francisco Valley, Brazilian semiarid region. Revista da Sociedade Brasileira de Medicina Tropical, vol. 51, no. 4, pp. 461-466. http://dx.doi.org/10.1590/0037-8682-00742018. PMid:30133628. 
GUSMÃO, J.D., BRITO, P.A. and LEITE, M.T.S., 2014. Perfil Epidemiológico da Leishmaniose Visceral no Norte de Minas Gerais, Brasil, no período de 2007 a 2011. Revista Baiana de Saúde Pública, vol. 38, no. 3, pp. 615-624. http://dx.doi.org/10.5327/ Z0100-0233-2014380300009.

HENN, G.A.L., RAMOS JÚNIOR, A.N., COLARES, J.K.B., MENDES, L.P., SILVEIRA, J.G.C., LIMA, A.A.F., AIRES, B.P. and FAÇANHA, M.C., 2018. Is Visceral Leishmaniasis the Same in HIV-coinfected Adults? The Brazilian Journal of Infectious Diseases, vol. 22, no. 2, pp. 92-98. http://dx.doi.org/10.1016/j.bjid.2018.03.001. PMid:29601790.

LIMA, M.E.S., NASCIMENTO, C.E.C., ERICEIRA, A.J.P. and SILVA, F.J.L.A., 2018. Perfil epidemiológico de crianças internadas com leishmaniose visceral em um Hospital Universitário do Maranhão. Revista da Sociedade Brasileira de Enfermeiros Pediatras, vol. 18, no. 1, pp. 15-20. http://dx.doi. org/10.31508/1676-3793201800003.

LOBO, K.S., BEZERRA, J.M.T., BRITO, L.M.O., SILVA, J.S. and PINHEIRO, V.C.S., 2013. Conhecimentos de estudantes sobre Leishmaniose Visceral em escolas públicas de Caxias, Maranhão, Brasil. Ciencia Er Saude Coletiva, vol. 18, no. 8, pp. 2295-2300. http:// dx.doi.org/10.1590/S1413-81232013000800013. PMid:23896911.

LOPES, E.G.P., MAGALHÃES, D.F., SILVA, J.A., HADDAD, J.P.A. and MOREIRA, E.C., 2010. Distribuição temporal e espacial da leishmaniose visceral em humanos e cães em Belo HorizonteMG, 1993 a 2007. Arquivo Brasileiro de Medicina Veterinária e Zootecnia, vol. 62, no. 5, pp. 1062-1071. http://dx.doi.org/10.1590/ S0102-09352010000500007.

QUEIROZ, M.J.A., ALVES, J.G.B. and CORREIA, J.B., 2004. Visceral leishmaniasis: clinical and epidemiological features of children in an endemic area. Jornal de Pediatria, vol. 80, no. 2, pp. 141-146. http://dx.doi.org/10.2223/1154. PMid:15079185.

OLIVEIRA, E., OLIVEIRA, D., CARDOSO, F. A., BARBOSA, J. R., MARCELINO, A. P., DUTRA, T., ARAÚJO, T., FERNANDES, L., DUQUE, D. and RABELLO, A., 2017. Multicentre evaluation of a direct agglutination test prototype kit (DAT-LPC) for diagnosis of visceral leishmaniasis. Parasitology, vol. 144, pp. 1964-1970. https://doi.org/10.1017/S0031182017001378. PMID: 28735574.
ORTIZ, R.C. and ANVERSA, L., 2015. Epidemiologia da leishmaniose visceral em Bauru, São Paulo, no período de 2004 a 2012: um estudo descritivo. Epidemiologia e Serviços de Saúde: Revista do Sistema Unico de Saúde do Brasil, vol. 24, no. 1, pp. 97-104. http://dx.doi.org/10.5123/S1679-49742015000100011.

PASTORINO, A.C., JACOB, C.M.A., OSELKA, G.W. and CARNEIROSAMPAIO, M.M.S., 2002. Leishmaniose visceral: aspectos clínicos e laboratoriais. The Journal of Pediatrics, vol. 78, no. 2, pp. 120-127. http://dx.doi.org/10.1590/S002175572002000200010 .

SOUSA, E.P., FREITAS, A.J.S., FAN, P. and OLIVEIRA, E.H., 2020. Evolução da leishmaniose visceral em São Luís, Maranhão: uma análise epidemiológica e temporal dos casos. Research. Social Development, vol. 9, no. 1, pp. 1-18. http://dx.doi.org/10.33448/ rsd-v9i2.2197.

SOUSA, N.A., LINHARES, C.B., PIRES, F.G.B., TEIXEIRA, T.C., LIMA, J.S. and NASCIMENTO, M.L.O. 2018. Perfil epidemiológico dos casos de Leishmaniose Visceral em Sobral-CE de 2011 a 2015. Revista de Políticas Públicas, vol. 17, no. 1, pp. 51-57.

SANTOS, M.A., RODRIGUES, S.L.C., NASCIMENTO, A.L.F., RODRIGUES, J.S. and GÓES, M.A.O., 2018. Leishmaniose Visceral: características clínico-epidemiológicas de casos e óbitos no estado de Sergipe. Revista de Epidemiologia e Controle de Infecção, vol. 8, no. 4, pp. 428-434. http://dx.doi.org/10.17058/reci.v8i4.11591.

SANTOS, G.M., BARRETO, M.T.S., SOUSA, M.J.D.M., SILVA, R.V.S., JESUS, R.L.R. and SILVA, H.J.N. 2017. Aspectos epidemiológicos e clínicos da leishmaniose visceral no estado do Piauí, Brasil. Revista Ciência e desenvolvimento, vol. 10, no. 2, pp. 142-153.

SCANDAR, S.A.S., SILVA, R.A., CARDOSO, J.R.P. and OLIVEIRA, F.H., 2011. Ocorrência de leishmaniose visceral americana na região de São José do Rio Preto, estado de São Paulo, Brasil. Boletim Epidemiológico Paulista, vol. 8, no. 88, pp. 13-22.

WORLD HEALTH ORGANIZATION - WHO. 2018. Surveillance of leishmaniasis in the WHO European Region, 2016 and Global leishmaniasis surveillance update, 1998-2016. Weekly epidemiological record $W H O$, n. 40, pp. 521-540. 